\title{
Narrating Ambivalence of Maternal Responsibility
}

\author{
by Eija Sevón \\ University of Jyväskylä \\ Sociological Research Online, Volume 12, Issue 2, \\ $<$ http://unw. socresonline.org.uk/12/2/sevon.html> \\ doi:10.5153/sro. 1527
}

Received: 12 Jul 2006 Accepted: 27 Feb 2007 Published: 30 Mar 2007

\begin{abstract}
Early motherhood and caring for the infant involve a moral ambiguity that is related to the questions of responsibility and vulnerability. By means of the ethics of care, motherhood can be understood as belonging to the moral domain, as relational, and as linked with everyday social situations. The culturally dominant narratives of 'good mothering' easily naturalise and normatise maternal agency. This study illustrates the process of adopting responsibility for the infant and the moral ambivalence that is inscribed in early maternal care. The data consist of four interview sessions with each of seven first-time mothers conducted during pregnancy and the first post-natal year. The interviews concentrated on events, relationships, routines, thoughts and feelings related to the mothers' daily caring for the baby. The women talked about their experiences drawing on two different narratives. The narrative of desirable responsibility unfolded the positive aspects of caring and responsibility for the baby. By means of this narrative, the women were able to give coherence to their lives as new mothers and to narrate the pleasure they felt in taking responsibility for their baby. In contrast, the narrative of maternal vulnerability showed the shadow side of maternal care focusing on the mothers' tiredness and distress. This narrative embodied 'moral monitoring' and 'epistemological struggles' between the dominant cultural narratives and the mothers' personal narratives. The study shows that early mothering is morally laden in two different ways simultaneously. Mothering itself is a moral disposition and practice characterised by ambivalence. The cultural narratives of 'good mothering' play a dual role in this process: they tempt women into pursuing intensive mothering, but at the same time they create an elusive moral imperative.
\end{abstract}

\section{Keywords: Care, Cultural Narratives, Ethics of Care, Morality, Motherhood, Narrative Research, Pleasure, Vulnerability}

\section{Introduction}

1.1 Responsibility, moral dilemmas, ambiguity and ambivalence can be seen as part and parcel of people's everyday lives (Bauman 1995, 1-3; Sevenhuijsen 1998, 16-19). The (feminist) ethics of care stresses responsibility, dependency and the needs of others as its starting point (Sevenhuijsen 1998, 107). It acknowledges everyday care as a crucial aspect of moral agency (Smart 1991). The moral aspects of family relations and parenting have recently been a focus of family research (see Finch 1994; May 2005; Murphy 2000; Ribbens McCarthy, Edwards \& Gillies 2000; Smart 1991; Smart \& Neale 1999). Family relations are closely tied to individuals' moral being (Miller 2005, 64). This article considers moral ambivalence in building up maternal agency during pregnancy and early motherhood, especially in relation to how mothers deal with their responsibility for their baby. Early maternal morality was studied through the narratives of seven Finnish first-time mothers.

1.2 According to the ethics of care early mothering is in its nature a moral practice, one in which the baby is wholly dependent on the carer. This usually transforms a mother's everyday life into a process of seeking to satisfy and learning to be responsive to her baby's needs. Care and taking responsibility for the baby form the basis for maternal morality. However, the overwhelming demands of the dominant cultural storylines of motherhood construct maternal responsibility in particular ways (Andrews 2002; Hays 1996; Vuori 2001). The cultural narratives of 'good mothering' forcefully connect both the mother's responsibility and the crucial role of the mother-child dyad to the child's normal development and well-being (Hays 1996; Murphy 2000; Phoenix \& Woollett 1991; Vuori 2001; Wetherell 1995). These narratives have a powerful impact on mothers' everyday lives, since they lead mothers to reflect on the moral quality of their mothering. 


\section{Maternal care and morality}

2.1 Drawing on the ethics of care ${ }^{[1]}$, I understand maternal care as linked to morality in everyday actions and situations. Care embodies moral dilemmas in the daily lives of people (Sevenhuijsen 1998, 24; Smart 1991; Smart \& Neale 1999). The ethics of care emphasises care as a relational phenomenon, and responsibility above abstract rights and rules (see Tronto 1994, 79; Sevenhuijsen 1998, 107). Care ethics also situates dependency and vulnerability within ordinary human subjectivity, instead of differentiating between able citizens and 'dependent' people (Sevenhuijsen 2000). Care is a social practice, in which others' needs form the basis, but which is also dependent on the norms and rules of good caring and on the relational dynamics between the actors involved (Sevenhuijsen 1998, 19-22). Maternal care can be defined as a mixture of attentiveness and sensitivity, responsibility and routines, which (at the beginning of motherhood) take time to be learned, but which once learned endow the mother with a specific competence (see Fisher \& Tronto 1990; Sevenhuijsen 2000).

2.2 In the ethics of care, responsibility is seen as an essential part of being human (Sevenhuijsen 2000). Selma Sevenhuijsen $(1998,83)$ defines care 'as an ability and a willingness to 'see' and to 'hear' needs, and to take responsibility for these needs being met'. The starting point for considering responsibility is thus the moral dilemma of how to deal with conflicting responsibilities for others and for the self as such in everyday situations (Sevenhuijsen 2000).

2.3 In the case of becoming a parent and a mother, parenthood embodies an assumption about responsibility for the baby (seeTronto 1994, 132; Murphy 2000). Responsibility involves moral ambiguities over how to understand and interpret the baby's needs, and what constitute the limits of responsibility and care for the baby (see Tronto 1994, 137-141). Mothers are obliged to deal with these questions in their everyday caring. The wider social environment is a part of this process. Thus, the morality of mothering is ambivalent. Responsibility over the child gives feelings of joy and satisfaction (Chase 2001, 77-78). However, the other side of the coin of maternal responsibility is the heavy a burden of caring and the isolation that mothers may feel (Arendell 2000; Fox \& Worts 1999; Hays 1996).

2.4 This ambivalence becomes more understandable when care is subjected to a more detailed analysis. A famous distinction is that between 'caring for' (work) and 'caring about' (love) (see Fisher \& Tronto 1990; Smart 1991). Carol Smart (1991) emphasises the need to understand 'caring for' as belonging to the moral domain, as a moral practice instead of a feminine, natural (maternal) instinct, and thus taken-for-granted, devalued and invisible (see also Tronto 1994, 118-119). Maternal care is thus a moral practice, but at the same time a moral disposition (see Sevenhuijsen 2000; Tronto 1994, 118-119).

2.5 Care involves feelings. In caring, one's own feelings and those of the other, and the relation between them are explicitly present (Sevenhuijsen 1998, 84). Care deals not only with feelings of love, empathy or involvement, but with feelings like guilt, shame, anger and aggression, and often these are interwoven (Sevenhuijsen 1998, 84). The concept of emotional work describes the dynamics of the emotional aspects and work aspect of care from the carer's point of view (see Arendell 2000; Strazdins \& Broom 2004). Emotional work can be seen as time, intention, actions and efforts that are made to meet emotional needs, to enhance the well-being of other family members and to maintain concord in the family (Strazdins \& Broom 2004). It can be demanding, and is often invisible, devalued, and unacknowledged (Strazdins \& Broom 2004). In the context of motherhood, Arendell (2000) suggests that emotional work is an ongoing process, where feelings shift in the course of the day and over longer period of time, depending on the child's behaviour and support obtained from others. In this process mothers' feelings also need to be managed and directed to bring them into line with the feelings mothers 'should feel' (Arendell 2000; Finch 1994, 207). Arendell also claims that women's negative feelings related to mothering are understudied.

2.6 Jane Ribbens (1998) illustrates the process of subordinating maternal feelings to moral evaluation. She $(1998,33)$ describes her maternal feeling voice as being under the control of her moral voice. Ribbens illuminates the process through which mothers 'learn' to submit their own feeling voices to moral monitoring: '.. the moral voices proclaim that the feeling voices are not relevant, and have no legitimacy. I cease to have a feeling voice other than through the moral monitoring. And this monitoring occurs so automatically, I have very little awareness that it is happening at all' (p. 33).

2.7 Other studies have also shown that (maternal) care involves moral dilemmas and that mothers aim at living their lives according to the ethics of care (see May 2005; Ribbens McCarthy, Edwards \& Gillies 2000, Smart \& Neale 1999). The danger in interpreting motherhood in terms of the ethics of care is associating the values of the ethics of care with the production of 'moral' motherhood. Sevenhuijsen $(1998,13)$ argues that if such values as connection, empathy and protective love are the main goals of moral reasoning, the 'good mother' remains the ideal character in the ethics of care. This runs the risk of establishing an opposition between being for or against the idea of 'female' morality (Davis 1994; Sevenhuijsen 1998, 13; Tronto 1993). This opposition is too simplistic and does not assist in understanding the multilayered 
problems and moral questions inherent in the relations between gender, power, care and ethics (Sevenhuijsen 1998, 13).

2.8 To summarise the focal points of the literature, in researching motherhood it is crucial that we understand the complexity of the concept of care (see Smart 1991). Discussion of the ethics of care and emotional work enables the analysis of the complexities of maternal responsibility and the mothers' contradictory feelings regarding their baby and care. In order to avoid reproducing the narrative about 'moral' motherhood, sensitivity is needed to recognise the manifold moral nature of mothering narratives.

\section{Studying maternal narratives}

3.1 Cultural narratives impact on mothers'personal narratives. The narrative approach provides a possibility to analyse contradictions between people's experiences, constructions of self and the impact of cultural (meta)narratives on their expectations and stories (Miller 2005, 20). Personal narratives tell about the emotional, moral and social aspects of life events (Hänninen \& Koski-Jännes 1999; Wood 2001). The narrative approach takes into account that women as mothers are embedded in the dominant culture and confront the various cultural and social narratives that surround family life (Andrews 2002). Motherhood, and especially the transition to motherhood, are loaded with cultural, scientific, professional and lay narratives (Andrews 2002; Miller 1998, 2000, 2005; Riessman 2002). The existing narratives of 'good mothering' and family life affect how mothers interpret their lives, because of the long history and scientific authority that lies behind them (Miller 2000, 2005; Riessman 2002; Phoenix \& Woollett 1991) and because polarising the divide between good and bad (Abbott 2002, 44-45; Chase 2001).

3.2 Cultural narratives offer meanings, identity categories, genres, and coherence for self-understanding (Hänninen \& Koski-Jännes 1999; Plummer 2001; Ricoeur 1991; Wood 2001). Cultural narratives are sought in situations of incoherence, when our experiences do not make sense (Wood 2001). We may identify with and adjust ourselves within cultural narratives, but we may also resist them and tell counter-narratives, or we may feel confused, ambivalent or bad about them (Andrews 2002; Hänninen \& Koski-Jännes 1999). Lois McNay $(2000,93)$ suggests that certain narratives remain powerful despite their lack of correspondence with present-time lives, because they offer assurance in maintaining coherent (gendered) identity. The narratives of romantic love, reproduction and fidelity are tenacious despite, for example, increasing voluntary nonmotherhood or growing divorce rates (McNay 2000, 93).

3.3 It is crucial to recognise that the dominant cultural narratives have moral force (Abbott 2002, 44). Sharon Hays (1996) describes present-day US mothering by the term intensive mothering. Intensive mothering is child-centred, expert-guided, emotionally absorbing, labour-intensive and financially costly, thus demanding time, constant involvement, emotional work and energy from women who become and are mothers (Hays 1996, 8). In the dominant cultural narratives the identity category 'mother' depicts a mother as an agent who selflessly devotes herself to the needs of the child, subordinates (gladly) her own needs and is responsible for the child and for the quality of her parenting (Hays 1996; Miller 2005, 110; Wetherell 1995, 231). Such dominant narratives may give rise to problems for mothers in making sense of and telling about their feelings and thoughts (Miller 1998, 2000, 2005; Ribbens 1998), at least when they collide with those narratives. Tina Miller (1998) uses the concept 'epistemological struggle', meaning struggles between different narratives or stories of mothering and one's own experiences. However, Lucy Bailey (1999) suggests that during pregnancy and the transition to motherhood, women may experience a refraction of the self. Motherhood may work as a narrative pivot for mothers constructing their reflexive biographies, and thus motherhood offers an opportunity for a renewed narrative moment (Bailey 1999). Becoming a mother may be transformative, giving new meaning and significance to life and changing the order of important matters in woman's life. This article focuses on the ambivalence of narrating maternal responsibility. This aim developed from my need to understand the two-fold nature of narrating motherhood.

3.4 Interviewing new mothers. This article is based on interviews with seven Finnish first-time mothers ${ }^{\text {[2]. }}$ The first interview was conducted during pregnancy, the second interview when the baby was approximately one month old, the third interview when the baby was about six months old, and the final interview when the child was around one year of age. Participation in the study was voluntary and the interview schedule was arranged according to the interviewees' wishes, mostly in their homes and according to their daily rhythms. All the interviewees agreed to all four interview sessions and described the interviews as therapeutic or important in order to reflect on their occasionally fragmented, 'messy' days.

3.5 Longitudinal interviewing made it possible to see the temporality of the narrated events and actions and enabled two different ways of telling: immediate and retrospective. First, in an immediate way the mothers talked about daily events, practices and routines with the baby. The nature of daily care consists in large part of non-verbal actions, grounded on embodiment, repetition and conventionality (Felski 2000; Miller 2000) without the need for continual reflection on everyday routines. However, the birth of the baby radically changed mothers' everyday lives, aspects of which 'came under the spotlight'. Phenomenological and 
narrative interviewing helped them to locate their talk on the level of everyday life (see Bergum 1997, 6-8; Chase 1995). Second, it was found in line with Miller (1998) that disclosures of the self were easier when done retrospectively. Many difficult events were narrated only retrospectively in a later interview. Longitudinal interviewing met the need to narrate 'small stories' of the moment and 'big stories' which contained reflection on events retrospectively (see discussion on 'small' and 'big' stories in e.g. Freeman 2006).

3.6 All the interviewees were becoming biological mothers for the first time. All were in heterosexual relationships, three of them cohabiting and four of them married. The women ranged in age from 21 to 31 at the time of the first interview. Three of the women were in full-time employment before their maternity leave, whereas four of them were studying, running a small business or working in temporary posts. In Finland maternity and parental leave combined last nine months and in the vast majority of cases mothers take both (Salmi \& Lammi-Taskula 2004, 40-41). This was true of all the present mothers. Three returned to paid employment after their parental leave, whereas four of them stayed at home. Their educational level was fairly high and corresponded to the general educational level of women in Finland, which tends to be higher than that of Finnish men (Tilastokeskus. http://www.stat.fi/til/vkour/2005/vkour_2005_2006-12-

05_tie_001.html). Six of the women might be classified as middle class on the basis of their own and their partners' education or occupation, and one as middle class according to her occupation and working class according to her spouse's occupation.

3.7 Analysis of maternal narratives. One important objective of the analysis was to try to understand why the stories were being told (Elliott 2005, 43; Franzosi 1998; Labov 1972). The stories people tell about their lives often embody moral evaluations about events, the self and a good life (Elliott 2005, 42-46; Labov 1972; May 2005; Plummer 2001, 187). The evaluative elements of narratives tell us what is important, dangerous, complex, hurting or unusual in those narratives (Labov 1972). I was able to discern the contradictory nature of maternal responsibility in the evaluative elements of the narratives. These evaluations included lengthy reflections on the mothers' own actions, feelings and thoughts. These reflections often used 'moral language'; for example, the women pondered what a mother should or should not do or what are good or bad, right or wrong ways of mothering (Kaskisaari 2004; Mauthner \& Doucet 1998).

3.8 It can be argued that the content and the evaluative dimension of narratives work together: the form and structure of how the mothers interpreted and evaluated life events might reveal the meaning of the life events for them (see Elliott 2005, 43). Many important things are often quite implicit in the narratives rather than being open 'confessions' or reflections, that is, possible to infer from their formal or linguistic aspects (Abbott 2002; Hyvärinen 1994, 57-63; Labov 1972). Narrative pace or the thickness of the narration, and repetition of sentences or events gave clues about the importance of the narrated experiences for the mother (see Labov 1972; May 2001, 85; Rimmon-Kenan 1983, 53). Thick description or a decelerated narrative pace is often linked to turning points in stories (May 2001, 85-86). In addition, the mothers' personal narratives related to the cultural narratives of 'good motherhood' (see Mauthner \& Doucet 1998). I use term intertextuality to refer to the idea of the (hidden) character of our personal narratives as social, as existing in dialogical relation to other narratives (see Vuori 2001, 90-93). By adopting the idea of intertextuality it was possible to listen to the echoes of the dominant cultural narratives in the mothers' narratives (see Andrews 2002; Jokinen 2004; Miller 1998; Vuori 2001); for example, reference to other narratives and the tone in which reference was made when mothers were making comparisons or drawing parallels with their own mothering.

3.9 In general, during pregnancy and immediately after the birth of the baby, mothers underlined the positiveness of the change in their lives before the child was born. However, the third interview showed some kind of a turning point in the women's narratives. The narratives contained very detailed descriptions of infant care and the mothers' own feelings in relation to it. Questions pertaining to being able to be a 'good' mother were discussed to a minor extent in every interview session; however, they tended to increase in the third interview. The stories were often about distress. In the fourth interview the narration quite often returned to more positive tone compared to the third interview. It is noteworthy that in the cases of some mothers, their narration centred most of the time, in all four interviews on the positive aspects of maternal agency, while other mothers reflected more on their own feelings of tiredness.

3.10 I identified in my data two distinct narratives. These I named the Narrative of desirable responsibility and the Narrative of maternal vulnerability. These two narratives described maternal responsibility differently. The differences were mostly in the content of the narratives, but there were also differences in how the mothers narrated care and responsibility (see Abbott 2002). These two narratives used somewhat different plotting, structure and language. Even if all the mothers' interviews involved both narratives, their relative predominance varied widely from interview to interview or mother to mother. All the names used in this article are pseudonyms. 
4.1 The narrative of desirable responsibility pertains to a more general framing narrative about adopting moral maternal agency. It was the landscape or background against which all the events were told. In all cases this narrative was more coherent, positive and linear in time than the narrative of maternal vulnerability. The mothers' relation to their child was mostly narrated in this mode when they talked about the baby, and with tenderness as they narrated watching the baby grow and develop. Already during pregnancy these women talked about their concern over the well-being of the unborn baby, pondering more generally over their future responsibility, financial situation, and life situation.

..of course, l've thought about the world of today, the horridness of the world and what kind of childhood my child will have, as my own childhood was happy and peaceful. Will he or she be allowed to experience the same? [I have wondered] what the world will bring with it, what will happen in the world, all this crime and so on. Like, what kind of world will he or she have?' (Ulla, age 27, first interview)

4.2 Responsibility came during pregnancy through the pregnant body. 'My own condition has been a very concrete example of how the baby already influences [my life], suddenly l'm not able to do all that I imagined l'd do'. (Elisa, age 28, first interview) In the later interviews, when these women told about themselves and their motherhood, the baby was present and very close physically, in an embodied and concrete way. Anne, 27 years old mother of twins, said in her third interview 'I hold them by my side; it's just so nice when they're near me. Then I try to heave them into their own bed, but I often fall asleep when I'm breastfeeding them'.

4.3 Kati, who was 21 years old, stated in her third interview that

'Mostly I'm the one, who is with him and who does everything, and he's so terribly dear and it's so easy to love such a smiling child, [...] he's the dearest thing in the world, I just stare at him all day long and wonder how we could have made such a marvellous thing. And it seems that he mostly takes after me..'

4.4 Responsibility was understood as a positive aspect of motherhood and included growing pride, competence and self-esteem regarding the mother's nurturing skills (see Fisher \& Tronto 1990). In this narrative the baby's needs and the mother's own needs coincided, and the mothers wanted to do their best in bearing responsibility and caring for the infant.

4.5 Elisa, like all these mothers, stressed being able to follow the growth and development of her child as the most pleasant aspect of mothering:

'It's also that you're unable to imagine beforehand how attached you're to your own child and how you keep on wondering at all the things she's doing, everything new and different, and how you say to yourself how can this child be so beautiful and wonderful (laughs) and so on, like it feels very good to be at home with her, doing our own thing, and the routines of everyday life, they take on a different meaning, now that l've this child. Whereas earlier home was only a place I visited every now and then and then I was rushing off somewhere else' (second interview)

4.6 This story is more about mental states: attached to, keep on wondering, say to yourself, and feels very good. The caring routines are discussed on a very general level - no description of the actual caring work is given - and they come across as light and easy. This was a common feature in this narrative. However, all the mothers stressed that caring for the baby was a process of learning - not a natural capability or instinct - to know the baby's needs and finding ways that would help in managing with the baby.

'At the beginning, I was very doubtful when they said in the [child health-care] clinic that you'll learn to tell, which cry is for hunger and which is for sleep or distress or whatever. I bet I will. I can't actually tell them apart all that well yet either, but really, it's, like, Lassi never cries for a nappy, so that can be left out, [...] actually, first I feed him, if he cries, he doesn't cry for anything else much.' (Kati, third interview)

4.7 If the routines of everyday life were not running smoothly, as when the child was difficult or the mother was tired, the mothers nevertheless described the child in positive terms. For example, Helena, a 28-yearold mother, whose child was not sleeping well, at the end of the fourth and last interview stated that 'even if we've had such a difficult time, it [being a mother] has been the best thing that has happened in my life, even if it has been difficult, I wouldn't go back, I mean, I'd do this all over again, because I've always thought that children are the meaning of life'. She also said in the third interview that she loved her child enormously and the child was the most important thing in the world to her, and that she would be able to handle the loss of her husband better than the loss of her child. 
4.8 The mothers reported easily following the guidelines that they had received from the child health-care clinics: for example, they aimed to breastfeed their babies for six months. In Finland, child-oriented breastfeeding for at least four to six months has been strongly promoted in the child health-care clinics (see Kuronen 1999, 212-216, cf. Murphy 2000). Breastfeeding is recommended in both medical and public health discourses to promote mother-infant bonding and infant development (Kuronen 1999, 211-212; Murphy 2000; Schmied \& Lupton 2001; Shaw 2003). However, experiences of breastfeeding are highly individual and may include tensions of tolerating interdependence (Schmied \& Lupton 2001). The interviewed mothers often cited breastfeeding as their most pleasurable activity with the baby. The primacy of the mother, which came through breastfeeding, was a source of pleasure for Kirsi, a 26-year-old mother, who at the very beginning of her motherhood described it as follows:
$\therefore$ when thinking about breastfeeding, it's just the thing for us two, I'm selfishly happy that nobody can replace me, l'm in a way indispensable during the breastfeeding months at least. [...] It's to do with security, I'm the basis for security in other ways too, because of feeding. Often, I'm the only one who can calm the baby. It's something that I look for too, somebody always says something like isn't it a childish feeling that you're the main one. But I feel as I feel. I can't help it.' (second interview)

4.9 The fact that these women had a rather high educational background might have affected the interviews insofar as these women might have had psychological knowledge, for example, about early attachment, and maybe thus had high standards regarding their own mothering. In other words, they were more familiar with the culturally dominant narratives of 'good mothering' (Duncan 2005; Perälä-Littunen 2004; Walkerdine \& Lucey 1989). For example, Kirsi already had considerable knowledge of breastfeeding, the father's role in parenting, and child development. In all her interviews she constructed a rather coherent picture of her maternal agency as an active and moral choice, reflected on thoroughly before pregnancy and throughout the whole year. She described staying at home with the baby as an active stay-at-home motherhood as opposed to a more static just-being-at-home-for-a-little-while motherhood. She was the only mother who evaluated her own maternal agency as more 'seriously taken' than that of many other mothers. She told the story of a devoted mother throughout the interviews. The following excerpt on breastfeeding shows the use of moral language and moral evaluations (see Kaskisaari 2004; Mauthner \& Doucet 1998; Ribbens 1998). At the same time, it is an example of learning to manage with the moral codes of mothering.

\begin{abstract}
'And in relation to breastfeeding, of course, when I set up my aims, I'd always looked down on people who read a book while breastfeeding or something. When you should be with the child. Then I realised, when I sometimes sit here and watch TV - how guilty I feel when I watch TV - but then I've realised that I'm here so many hours a day that I 've had to give up this sort of principle.' (Kirsi, second interview)
\end{abstract}

4.10 The mothers who were unable to continue full breastfeeding, wanted to carry on doing it at least partially for the baby's sake and to preserve the intimate mother-infant bond (cf. Murphy 2000). However, breastfeeding was also one of the most lengthily discussed, reflected on and ambivalent issues in the interviews. For example, Helena, stated in her third interview 'even if we've had enormous trouble with breastfeeding, I find it the most marvellous thing about being with the baby, when the milk flows well'.

4.11 Rhonda Shaw's (2003) theoretical position enables me to link (breast)feeding to the moral domain. As she $(2003,60)$ puts it: 'the relationship between a breastfeeding mother and her infant $[\ldots]$ is also an elementary ethical relation since, from the perspective of the one giving, the infant is an other whose being commands respect and whose needs must be met'.

4.12 Taken together, through the narrative of desirable responsibility the interviewed mothers strongly and positively described their newfound maternal ethics of care, in which they learned to see, hear and take care of the needs of the baby. The plot construed a clear transformation in the women's lives compared to their lives before the baby, a transformation which was or turned out subsequently to be a positive one and which they narrated as actively chosen already before or during pregnancy (cf. Bailey 1999; Sevón 2005). The purpose of the narrative was to be able to describe motherhood and the child as transformers, signifiers that changed the whole foundation of the mothers' lives. Underlying this maternal moral agency was a specific kind of relationality: being for, connection with, responsibility for the baby, which developed through embodied practices, closeness and the feelings of pleasure that the baby and caring for the baby aroused. Further, this narrative also accorded with the cultural narratives of 'good mothering'; the mothers constructed their new identities as mothers acting in the best interests of their children and as committed, competent and morally engaged mothers (cf. May 2005; Murphy 2000; Ribbens McCarthy, Edwards \& Gillies 2000; Smart \& Neale 1999). 
5.1 On the one hand, the mothers produced a rather coherent picture about becoming a mother, as described above. However, on the other hand their stories took many forms and were in some cases partly, and in some cases dominantly, rather fragmented. In the narrative of maternal vulnerability the plot was more ruptured than linear. At its extreme the last three interviews with one mother, Helena, comprised a continuous narrative of a motherhood experienced as chaotic. The narrative of maternal vulnerability told or tried to tell about the darker side of caring for a young child, about emotional work and difficulties in mothering, and about discord between the needs of the baby and the needs of the mother.

5.2 Tiina was a 31-year-old mother and she was not able to obtain much respite from caring. The reason for this was the fact that her spouse worked long hours. Further, she herself did not want to leave the child with her spouse in order to go out, because she would have been so worried about the baby while away from home that going out would not have helped her to get any rest. Tina said that 'mothering was chipping away at her ego'.

IInterviewer: What things or situations cause you to feel guilt?[...]

Tiina: [...] occasionally, I'm extremely tired and then I feel that I should't allow myself to be angry with the child. Occasionally I get the feeling that couldn't you [the baby] just quieten down. [...] And the child, of course, I feel, senses that. Thus he gets more upset. Of course, I try to count to ten and I feel heavy at heart because I can't. I try to sort of blank out my anger. [...]

I: Are your emotional reactions perhaps rather intense?

T: Sort of primaeval. Difficult to control.

I: Does it also happen when you are alone with the baby and are trying to be sort of calm.. [overlapping speech]

T: .. Yes, because I know of course that a parent is an adult. Like I should be able to control my feelings and sort of be the calm one. And then, a mother is stable and these kinds of things. [...] I just hold on to the idea that a mother has a long fuse. Because the child doesn't do such things on purpose. [...] It's more to do with one's own frustration when I can't react to the child's bad moods. It affects me quite strongly, if I haven't slept well. Like, when I've slept well, I can. Then, if I've read about something awful in the news, [...], I feel a kind of gratitude because everything is all right with us. What am I complaining about here? Everything's been all right.' (third interview)

5.3 There was similarity in the form, structure and the narrative means in all the stories telling about maternal vulnerability. Tiina's story is an illustrative example: it includes description of the conflict between the baby's and the mother's feelings, maternal frustration, anger, emotional work, and a moral evaluation of her feelings. A close look at the excerpt above shows a common structure found in this narrative (see Labov 1972). The beginning of the narrative sets out the situation in which Tina is tired. Then she 'confesses' that she behaves wrongly or is not able to act correctly: 'occasionally, I'm extremely tired and then I feel that I shouldn't allow myself to be angry with the child'. Then she gives a rather normative evaluation, about how a mother or an adult should be able to behave '.. Yes, because I know of course that a parent is an adult. Like I should be able to control my feelings and sort of be the calm one.'(cf. Ribbens McCarthy, Edwards \& Gillies 2000). What comes next, is a qualification, a reference to something which functions as extenuating circumstances: 'It affects me quite strongly, if I haven't slept well'. The narrative ends with the statement about how well the things are, generally speaking. In addition, the echoes of comparing her own motherhood to the ideal of motherhood can be heard in the narrative: 'a mother is stable' or 'I just hold on to the idea that a mother has a long fuse'(see Mauthner \& Doucet 1998; Miller 1998, 2005). Moral evaluations are at the centre of narratives about vulnerability (see Labov 1972; Plummer 2001, 187). To put it another way, moral monitoring, which is how Ribbens (1998) describes it, is exactly what Tina's narrative is about.

5.4 The interviewed women spoke at length about the rhythms of the baby, the rhythms of the day and about the rhythmlessness of their being, as repetitive events which were frequently interrupted. They described the moment-by-moment nature of daily care, the conflict between linear time and the mothers' 'own' time and the round-the-clockness of their lives. In this narrative maternal agency emerged, more generally, through countless repetitive actions, the developing of routines and habits, and ruptured routines, and through good moments and bad moments. The contradictions surrounding time and the nature of temporality that inform maternal agency can be understood in the light of Rita Felski's (2000) idea about repetition. She situates repetition as a temporal mode in everyday life and sees it as structured by the contradiction between linear and cyclical time. In this narrative, in which stationary time and change alternate, the mothers experienced a contradiction between cyclical and linear time, and between the baby's rhythms and their own rhythms and time. 
day it's today. Every day is similar or every day is totally different. Here there are no holidays.' The mothers talked about days passing quickly, but at the same time, about long hours of caring, breastfeeding, comforting and carrying the baby. They waited for their spouses to come home from work, told about their difficulties in getting the day started, and about the lack of time for themselves. Usually these temporal contradictions diminished during the first year, but in the case of a few mothers they were so considerable as to affect the whole of the first year.

5.6 In her third interview when her twins were six months, Anne described time as something the mother cannot plan or follow, i.e., it is determined from outside. She stated:

'the days are going quite well. I'm, of course, at home with them. The days go by on their terms almost totally. [She describes the twins' daily rhythms at length.] l've to say that my work with them, I don't have moments left over for myself at all. Afternoon naps are often so short that they pass unnoticed. Some days, if they really sleep for two hours, it's such a luxury that I'm able to do my housework in peace, whereas normally I try to do it in a rush [...]. I don't have problems passing the time.'

5.7 The narrative repeated the references to time, of how the twins structured Anne's time almost totally. Later in the interview Anne talked about her and the twins 'night life' with the constant breastfeeding. I asked if she was tired, but she did not want to stop breastfeeding at night, because the twins did not seem to want to suckle in the daytime and she thought that the children would give up suckling when they were ready to. Anne's narrative is about an attempt surrender oneself to the needs of the baby [babies].

5.8 This was one general mode of narrating maternal responsibility, that is, not reflecting on one's own feelings or senses, but simply reporting routines. It was not until the next interview, a half a year later that Anne talked about how tired and exhausted she had been at the time of the previous interview. Not admitting one's tiredness might be seen function a coping strategy. However, as Miller $(1998,59)$ states: 'voicing experiences which are not thought to be commonly shared, to a researcher, may be perceived as risky'. It was easier for the mothers to admit to many difficult events afterwards. References to 'awful yesterdays' were also common. I was able to detect features in their maternal vulnerability narratives that resembled the chaos narrative found by Arthur Frank $(1995,79-114)$ in his study on illness and ill people. A chaos narrative has no narrative order and it lacks coherence or continuity; one event does not lead to the next event (Frank 1995, 97). Frank $(1995,98)$ writes that 'to turn the chaos into a verbal story is to have some reflective grasp of it'. It requires distance, because lived chaos makes reflection and storytelling impossible (Frank 1995, 98).

5.9 Helena's three interviews consisted of a single long, gradual narrative about a sleepless baby and the problems it caused ${ }^{[3]}$. Her whole life was turning into a disaster. Helena herself was tired and exhausted as was her spouse. She felt that the personnel at the child health-care clinic were unhelpful when they suggested the problem could be solved by asking the father to care for the baby. The only relief was the help they got from Helena's mother. Helena said 'I feel really stupid, I have only one child and I can't cope with him'. All three interviews told about her efforts to try to get her baby to sleep and their life 'back to normal' and, simultaneously, to make sense of the somewhat chaotic start of her motherhood. However, notably for the purpose of this study, also her interviews included both narratives: within the first, she recounted mothering as the best thing that had ever happened to her (see paragraph 4.7).

5.10 Helena tried to determine the reasons for her baby's crying throughout all her interviews. She was also waiting for the story of 'true' motherhood to begin. She ended her second interview by emphasising her inability to enjoy the baby enough and hoping for a better future:

'I imagine that life will begin to run more easily now, we're getting on with it, now we've got started, it was really tricky at the beginning. Life smiles, when I get enough sleep, but when tiredness hits [...] So, it has bothered me that I haven't been able to enjoy the baby properly, because I've been so awfully tired. [...] now I believe, if the nights are going to go as easily as now, I can start to plan what we might do.'

5.11 She often narrated her experiences implicitly or more openly in relation to the narratives of 'good mothering', according to which the mother is 'naturally' able and competent to care for her child (Wetherell 1995). Helena began her fourth interview by describing the positive changes in their family life: 'the baby has vanished and he has now become a little boy'. Then she continued:

'I haven't cried as much as during this year in my whole life, [...], I've been thinking that almost all diseases can be cured, but that it's not possible to help a person who is in a way in the normal situation of having a healthy baby, such a family cannot be helped, it's a serious flaw.' 


\begin{abstract}
$\therefore$ my mother has tried to tell me many times during the year that it's no use talking about it to anyone, as I myself have tried to get understanding, support and help, and I've been of the opinion that if I don't talk to somebody, I won't get any help. We should all just try to survive by ourselves and then after a year we'll see whether we survived or not. [...] It would be like this was the kind of baby we got, so our life may be disrupted for a year or two, then they'll [the personnel at the clinic] see if we survive or not. It hasn't been always so certain that we'd survive, if we hadn't my mom, we probably wouldn't have been able to survive.'
\end{abstract}

$5.13 \mathrm{It}$ is not easy for a mother to admit her incompetence. One of the strongest taboos related to mothering seems to be that the mother is unable to care for and take care of her baby (see Miller 2005, 100-101). In this sense, Helena's story is courageous and revealing. Helena recounted her attempts to cope with a sleepless baby using a decelerated pace and much repetition (see May 2001, 85). Her story also shows the struggle between of being honest about her efforts to cope with her situation and trying to maintain maternal agency. At the same time, her narrative runs counter to the dominant narratives about mothering (see Andrews 2002). In general, chaos narratives are difficult to hear, since they invoke anxiety and lack a 'proper' plot or narrative thread, and because the teller reveals vulnerability, futility and impotence instead of competence and progress (Frank 1995, 97-98). This is also very true of Helena's narrative, and more generally, of maternal vulnerability.

5.14 To summarise, at the core of the narrative of maternal vulnerability was the conflict between the needs of the mother and the needs of the baby. The purpose or point of telling was to try to make sense of and attribute coherence to the experiences and contradictory feelings related to infant care and to cope with the challenges of early motherhood. The narrative of maternal vulnerability mostly dealt with the shadow-side of care: the contradictions of time, being alone and trying to cope with the baby, feelings of tiredness, incompetence and a heavy burden of emotional work, even collapse. The narrative pace was decelerated: individual events were reported in great detail, and events and feelings were rehearsed and evaluated (see May 2001, 85). The narration often contained qualifications that made those events and feelings sound more like exceptions than the rule.

5.15 By drawing on the concept of emotional work, the ambivalent emotions, present in the narrative of vulnerability become intelligible (see Arendell 2000; Strazdins \& Broom 2004). In narrating their motherhood, the women made close connections between practical and emotional work. At the same time, they described diverse practical, embodied duties: nestling the baby, (breast)feeding, carrying the baby, putting the baby to sleep, upheaving, nappy changing, and getting up at night, and the almost intolerable amount of responsibility and emotional work they had to do to be responsive to the baby's feelings, moods and needs. These women also tried to make sense of their own feelings of tiredness, incompetence, unfairness, anger and disappointment (see Arendell 2000). These attempts caused most of the feelings of ambivalence and inexplicability. They also did emotional work to square their feelings with the hegemonic cultural storylines. Vulnerability is manifested in the ruptures in the mothers' images of themselves as good, competent and caring mothers. Their sense of maternal agency is injured.

5.16 Care means giving up one's time for an other (Fisher \& Tronto 1990). The other, the child, determined maternal agency. Early mothering develops through becoming aware of the demands of the infant and how these demands restrict the mother's everyday life. Sevenhuijsen $(1998,13)$ warns about discounting the 'shadow-side of care'. She names such factors as the existence of conflict, aggression, ambivalence and discord in feelings and experiences related to care. Intensive mothering binds the mother easily and tightly to the child, home and, too often, to loneliness (see Fox \& Worts 1999; Hays 1996).

\title{
Conclusions
}

6.1 How are two different narratives women used in describing their mothering experiences to be understood? In their everyday lives, they had made a conscious attempt to take responsibility for the wellbeing of their babies, as was shown in the narrative of desirable responsibility. In this sense these women's narrative of desirable responsibility was about 'good mothering'. When talking about the 'proper' aspects of mothering, the women were able to place and identify themselves within the narratives of 'good mothering', create, and recreate their identities and give coherence to their lives as responsible, new mothers (see Hänninen \& Koski-Jännes 1999; Miller 2005; Murphy 2000; Wood 2001).

6.2 However, the narrative of desirable responsibility did not enable talk about the negative feelings or ambivalence of becoming a mother. This is because care is both a moral activity and disposition (Sevenhuijsen 2000), and the process of becoming a mother is a process of digesting this disposition. Early maternal agency involves consciously putting oneself at the disposal of the other, acting on the 
baby's terms. The narrative of maternal vulnerability was told through disruptions in activity, as exceptions to the norm, and alongside the first narrative, in effort to pursue and maintain the requisite moral disposition. The culturally acceptable way of talking about becoming a mother does not allow the 'negative' aspects of mothering and caring to be narrated (see Arendell 2000; Miller 2005; Murphy 2000). It is this that makes these two separate and very differently constructed narratives necessary.

6.3 The narratives of 'good mothering' were the landscape behind experiencing and narrating mothering. The narrative of maternal vulnerability contained moral evaluations, especially vocabulary and words that referred to the right or wrong ways of feeling and acting as a mother (Doucet \& Mauthner 1998; Kaskisaari 2004; Ribbens 1998). The use of a moral vocabulary quite often disclosed an internal conflict or contradiction. This 'moral monitoring' suddenly flashed out in the interviews. Such moments of 'epistemological struggle' existed in daily caring: when the mother did not bother, was not able, could not, and was manifested in questions concerning one's ways of feeling, thinking and acting: What I am supposed to feel?; How I am supposed to act?; Is the way I act good (or bad) for the baby?; Can I feel what I feel? The mother's own feeling voice, moral voice(s), the voices of the narratives of 'good mothering' and her attempt to create her mothering story for herself and to voice her story to the researcher led to a discordant outcome on the part of the mother (see Miller 1998; Ribbens 1998).

6.4 Caring for a baby invokes specific kinds of emotionality and morality. Emotionality is based on deep and embodied feelings of joy and pleasure, but also on emotional work and negative feelings related to care. Morality, in turn, is related to the ethics of care (Sevenhuijsen, 1998; Tronto 1994). The beginning of motherhood is narrated as the beginning of a process towards agency, in which the presence, dependence and the needs of the other have to be taken seriously. Questions about responsibility, empathy, love and concern for the other are irreversibly a part of a mother's everyday life. The two narratives tell about the ambivalence of maternal responsibility: feelings of competence and incompetence, pleasure, commitment and exhaustion, paralysing and empowering feelings at the same time.

6.5 Early maternal agency is morally laden in two different ways simultaneously. Firstly, maternal agency is a given, fixed composition in the dominant cultural narratives (see Hays 1996; Riessman 2002; Vuori 2001). These narratives of 'good mothering' exclude the experiences of mothers and thus easily extinguish maternal agency. The dominant narratives of mothering have moral obligatory power: all mothering practices are moral practices; even the most trivial practices are morally laden (Chase 2001; Murphy 2000; Ribbens 1998). This leads mothers to question and reflect on their own morality in their daily actions. These narratives had a dual role in interviewed women's lives: they tempted them into pursuing intensive mothering, but at the same time they created an elusive moral imperative. Further, the dominant narratives do not acknowledge the substantial differences between infants' individual temperaments and characters which in turn mean wide variation in the heaviness or lightness of maternal care. Secondly, the baby as a significant other for the mother, the baby's dependence on the carer, the helplessness and vulnerability of the baby without the carer make the inevitability of care visible. Practical mothering, having responsibility for and caring about the baby together make mothering a moral disposition and practice which has an ambivalent nature. The morally laden cultural narratives of motherhood enhance significantly this ambivalence.

\section{Notes}

${ }^{1}$ The idea of the ethics of care is grounded on Carol Gilligan's theory (1982) about the different voice of women and the ethics of care. The theory has been both much debated and further elaborated (see Larrabee 1993; Sevenhuijsen 1998; Smart 1991; Tronto 1994).

2 Two of the interviewed women were recruited through the snowball technique. Five of the interviewed women came through an official clearance to recruit women from maternity health care clinics in one Finnish town. I introduced my dissertation study in prenatal classes and handed out an information sheet containing my contact information for the mothers-to-be.

${ }^{3}$ The transcripts of these three interviews cover 97 single-spaced pages.

\section{Acknowledgements}

I want to thank the reviewers for their helpful comments on my manuscript. I am also very grateful to Marjo Kuronen (PhD) at the University of Jyväskylä for her support and comments on the manuscript. 
ABBOTT, P. H. (2002) Cambridge Introduction to Narrative Research. Cambridge University Press.

ANDREWS, M. (2002) 'Introduction: Counter-Narratives and the Power to Oppose', Narrative Inquiry, Vol. 12, No. 1, pp. 1-6.

ARENDELL, Terry (2000) 'Conceiving and Investigating Motherhood: The Decade's Scholarship', Journal of Marriage and the Family, Vol. 64, No. 4, pp. 1192-1207.

BAILEY, L. (1999) 'Refracted Selves? A Study of Changes in Self-ldentity in the Transition to Motherhood', Sociology, Vol. 33, No. 2, pp. 335-352.

BAUMAN, Z. (1995) Life in Fragments: Essays in Postmodern Morality. Oxford: Blackwell.

BERGUM, V. (1997) A Child on Her Mind: The Experience of Becoming a Mother. Westport, CT: Bergin \& Garvey.

CHASE, S. E. (1995) 'Taking Narrative Seriously: Consequences for Method and Theory in Interview Studies' in R. Josselson \& A. Lieblich (editors) Interpreting Experience. The Narrative Study of Lives, Volume 3. Thousand Oaks, CA: Sage, pp. 1-26.

CHASE, S. E. (2001)'“Good" Mothers and "Bad" Mothers' in S. E. Chase \& M. F. Rogers (editors) Mothers \& Children. Feminist analyses and Personal Narratives. New Brunswick: Rutgers University Press, pp. 3047.

DAVIS, K. (1994) 'What's in a Voice? Methods and Metaphors', Feminism \& Psychology, Vol. 4, No. 3, pp. 353-361.

DUNCAN, S. (2005) 'Mothering, Class and Rationality', The Sociological Review, Vol. 53, No. 1, pp. 50-76.

ELLIOTT, J. (2005) Using Narrative in Social Research. Qualitative and Quantitative Approaches. London: Sage.

FELSKI, R. (2000) 'The Invention of Everyday Life', New Foundations, Vol. 39, pp. 15-31.

FINCH, J. (1994) Family Obligations and Social Change. Second edition (first edition 1989). Cambridge: Polity Press.

FISHER, B. \& TRONTO, J. (1990) 'Toward a Feminist Theory of Caring' in E. K. Abel \& M. K. Nelson (editors) Circles of Care. Work and Identity in Women's Lives . Albany, NY: State University of New York Press.

FOX, B. \& WORTS, D. (1999) 'Revisiting the Critique of Medicalized Childbirth', Gender \& Society, Vol. 13, No. 3, pp. 326-347.

FRANK, A. W. (1995) The Wounded Storyteller: Body, Illness, and Ethics. University of Chicago Press: Chicago.

FRANZOSI, R. (1998) 'Narrative Analysis - or Why (and How) Sociologists Should Be Interested in Narrative', Annual Review of Sociology , Vol. 24, pp. 517-554.

FREEMAN, M. (2006) 'Life "on Holiday”? In Defence of Big Stories', Narrative Inquiry, Vol. 16, No. 1, pp. 131-138.

GILLIGAN, C. (1982) In a Different Voice: Psychological Theory and Women's Development. Cambridge, MA: Harvard University Press.

HAYS, S. (1996) The Cultural Contradictions of Motherhood . New Haven: Yale University Press.

HYVÄRINEN, M. (1994) Viimeiset taistot [Last Struggles]. Tampere: Vastapaino.

HÄNNINEN, V. \& KOSKI-JÄNNES, A. (1999) 'Narratives of Recovery from Addictive Behaviours', Addiction, Vol. 94, No. 12, pp. 1837-1848.

JOKINEN, E. (2004) 'The Makings of Mother in Diary Narratives', Qualitative Inquiry, Vol. 10, No. 3, pp. 339-359.

KASKISAARI, M. (2004) 'Työstä uupunut: kärsimyksen modaalisuus' [Exhausted from Work: the Modality 
of Suffering] in E. Jokinen, M. Kaskisaari \& M. Husso (editors) Ruumis töihin! Käsite ja käytäntö [Get the Body to Work! Concept and the Practice] Tampere: Vastapaino, pp. 125-149.

KURONEN, M. (1999) The Social Organisation of Motherhood - Advice Giving in Maternity and Child Health Care in Scotland and Finland. Doctoral Thesis, University of Stirling.

LABOV, W. (1972) Language in the Inner City: Studies in the Black English Vernacular. Oxford: Blackwell. LARRABEE, M. (editor) (1993) An Ethic of Care: Feminist and Interdisciplinary Perspectives. New York: Routledge.

MAUTHNER, N. \& DOUCET, A. (1998) 'Reflections on a Voice-centred Relational Method: Analysing Maternal and Domestic Voices' in J. Ribbens \& R. Edwards (editors) Feminist Dilemmas in Qualitative Research. Public Knowledge and Private Lives. London: Sage, pp. 119-146.

MAY, V. (2001) Lone Motherhood in Finnish Women's Life Stories. Creating Meaning in a Narrative Context. Turku: Åbo Akademi University Press.

MAY, V. (2005) 'Divorce in Finnish Women's Life Stories: Defining 'Moral' Behaviour', Women's Studies International Forum, Vol. 28, pp. 473-483.

MCNAY, L. (2000) Gender and Agency. Reconfiguring the Subject in Feminist and Social Theory. Cambridge: Polity Press.

MILLER, T. (1998) 'Shifting Layers of Professional, Lay and Personal Narratives: Longitudinal Childbirth Research' in J. Ribbens \& R. Edwards (editors) Feminist Dilemmas in Qualitative Research. Public Knowledge and Private Lives. London: Sage, pp. 58-71.

MILLER, T. (2000) 'Losing the Plot: Narrative Construction and Longitudinal Childbirth Research', Qualitative Health Research, Vol. 10, No. 3, pp. 309-323.

MILLER, T. (2005) Making Sense of Motherhood. A Narrative Approach . Cambridge University Press.

MURPHY, E. (2000) 'Risk, Responsibility, and Rhetoric in Infant Feeding', Journal of Contemporary Ethnography, Vol. 29, No. 3, pp. 291-325.

PERÄLÄ-LITTUNEN, S. (2004) Cultural Images of a Good Mother and a Good Father in Three Generations. Jyväskylä Studies in Education, Psychology and Social Research 239.

PHOENIX, A. \& WOOLLETT, A. (1991) 'Motherhood: Social Construction, Politics and Psychology' in A. Phoenix, A. Woollett \& E. Lloyd (editors) Motherhood. Meanings, Practices and Ideologies. London: Sage, pp. 13-27.

PLUMMER, K. (2001) Documents of Life 2. An Invitation to a Critical Humanism. London: Routledge.

RIBBENS, J. (1998) 'Hearing my Feeling Voice? An Autobiographical Discussion of Motherhood' in J. Ribbens \& R. Edwards (editors) Feminist Dilemmas in Qualitative Research. Public Knowledge and Private Lives. London: Sage, pp. 24-38.

RIBBENS MCCARTHY, J., EDWARDS, R. \& GILLIES, V. (2000) 'Moral Tales of the Child and the Adult: Narratives of Contemporary Family Lives under Changing Circumstances', Sociology, Vol. 34, No. 4, pp. 785-803.

RICOEUR, P. (1991) 'Life in Quest of Narrative' in D. Wood (editor) On Paul Ricoeur: Narrative and Interpretation. London: Routledge, pp. 20-33.

RIESSMAN, C. K. (2002) 'Accidental Cases: Extending the Concept of Positioning in Narrative Studies. Commentary on Molly Andrews' Memories of Mother: Counter-Narratives of Early Maternal Influence; Narrative Inquiry 12(1), pp. 7-27', Narrative Inquiry, Vol. 12, No. 1, pp. 37-42.

RIMMON-KENAN, S. (1983). Narrative Fiction: Contemporary Poetics. London: Methuen.

SALMI, M. \& LAMMI-TASKULA, J. (editors) (2004) Puhelin, mummo vai joustava työaika? Työn ja perheen yhdistämisen arkea. [Phone, Grandma or Flexible Working Hours? Everyday life in Balancing Work and Family.] Helsinki: Stakes.

SCHMIED, V. \& LUPTON, D. (2001) 'Blurring the Boundaries: Breastfeeding and the Maternal Subjectivity', 
Sociology of Health \& Illness, Vol. 23, No. 2, pp. 234-250.

SEVENHUIJSEN, S. (1998) Citizenship and the Ethics of Care. Feminist Considerations on Justice, Morality and Politics. London: Routledge.

SEVENHUIJSEN, S. (2000) 'Caring in the Third Way: The Relation between Obligation, Responsibility and Care in Third Way Discourse', Critical Social Policy, Vol. 20, No. 1, pp. 5-37.

SEVÓN, E. (2005) 'Timing Motherhood: Experiencing and Narrating the Choice to Become a Mother', Feminism \& Psychology, Vol. 15, No. 4, pp. 461-482.

SHAW, R. (2003) 'Theorizing Breastfeeding: Body Ethics, Maternal Generosity and the Gift Relation', Body \& Society, Vol. 9, No. 2, pp. 55-73.

SMART, C. (1991) 'The Legal and Moral Ordering of Child Custody', Journal of Law and Society, Vol. 18, No. 4 , pp. $485-500$.

SMART, C. \& NEALE, B. (1999) Family Fragments? Cambridge: Polity Press.

STRAZDINS, L. \& BROOM, D. H. (2004) 'Acts of Love (and Work). Gender Imbalance in Emotional Work and Women's Psychological Distress', Journal of Family Issues, Vol. 25, No. 3, pp. 356-378.

TILASTOKESKUS. [Statistics Finland] Väestön koulutusrakenne. [Educational structure of population] (2006) <http://www.stat.fi/til/vkour/2005/vkour_2005_2006-12-05_tie_001.html> 18.12.2006.

TRONTO , J. (1993) 'Beyond Gender Difference to a Theory of Care' in M. Larrabee (editor) An Ethic of Care: Feminist and Interdisciplinary Perspectives. New York: Routledge, pp. 240-257.

TRONTO, J. (1994) Moral Boundaries. A Political Argument for an Ethic of Care. New York: Routledge.

VUORI, J. (2001). Äidit, isät ja ammattilaiset. Sukupuoli, toisto ja muunnelmat asiantuntijoiden kirjoituksissa [Mothers, Fathers and Professionals. Gender, Repetition and Variety in Expert Texts] Tampereen Yliopistopaino.

WALKERDINE, V. \& LUCEY, H. (1989) Democracy in the Kitchen: Regulating Mothers and Socialising Daughters. London: Virago.

WETHERELL, M. (1995) 'Social Structure, Ideology and Family Dynamics: The Case of Parenting' in J. Muncie, M. Wetherell, R. Dallos \& A. Cochrane (editors) Understanding the Family. London: Sage pp. 213256.

WOOD, J. T. (2001) 'The Normalization of Violence in Heterosexual Romantic Relationships: Women's Narratives of Love and Violence', Journal of Social and Personal Relationships, Vol. 18, No. 2, pp. 239261. 